\title{
Molecular identification of Sarcocystis halieti in the muscles of two species of birds of prey from Spain
}

Petras Prakas $^{1 *} \mathbb{C}$, Antonio Bea ${ }^{2}$, Evelina Juozaitytè-Ngugu' ${ }^{1}$ Iñaki Olano², Diego Villanúa ${ }^{3}$, Saulius Švažas ${ }^{1}$ and Dalius Butkauskas'

\begin{abstract}
Background: Members of the genus Sarcocystis are protozoan parasites characterized by a prey-predator two-host life-cycle. Sarcocysts are formed in the muscles or central nervous system of the intermediate host $(\mathrm{IH})$, while sporocysts develop in the small intestine of the definitive host (DH). Various birds of prey have been confirmed to be DH for Sarcocystis spp. Three Sarcocystis species, S. wobeseri, S. halieti and S. falcatula, have been identified in the muscles of birds of prey, of which the latter are known to be pathogenic and can cause encephalitis in various birds. The aim of this study was to identify Sarcocystis spp. in the muscles of birds of prey from Spain.
\end{abstract}

Methods: Between 2019 and 2020, muscle tissue samples taken from 59 birds of prey admitted to the Wildlife Recovery Centre in llundain (Navarra, Spain) were examined for the presence of Sarcocystis spp. Sarcocysts in fresh squashed samples were morphologically characterized under the light microscope (LM). Sarcocystis spp. were identified by means of $28 \mathrm{~S}$ ribosomal RNA and internal transcribed spacer 1 sequence analysis.

Results: Microscopic examination of squashed tissue samples stained with methylene blue revealed the presence of sarcocysts in three of the 59 (5.1\%) birds examined. Only one sarcocyst type was observed under the LM. Sarcocysts were thread-like $(1050-2160 \times 130-158 \mu \mathrm{m})$ and had a thin $(0.7-1.4 \mu \mathrm{m})$ and smooth cyst wall. Septa divided the cysts into compartments filled with banana-shaped $(5.9 \times 1.7 \mu \mathrm{m})$ bradyzoites. On the basis of DNA sequence results, S. halieti was identified in the western marsh harrier (Circus aeruginosus) and the black kite (Milvus migrans) for the first time. Sarcocysts of S. halieti were shorter and wider compared to those observed in the great cormorant (Phalacrocorax carbo) and the herring gull (Larus argentatus). According to current knowledge, S. halieti may infect birds belonging to four different orders: Suliformes, Charadriiformes, Strigiformes and Accipitriformes.

Conclusions: This is the first report of $S$. halieti in the western marsh harrier and the black kite as IH. So far, little research has been conducted on birds of prey as $\mathrm{IH}$ for Sarcocystis spp. These results indicate that further studies combining morphological, histopathological, and molecular methods are required.

Keywords: Sarcocystis halieti, Birds of prey, Molecular identification, ITS1, 28S rRNA

*Correspondence: prakaspetras@gmail.com

${ }^{1}$ Nature Research Centre, Akademijos 2,08412 Vilnius, Lithuania

Full list of author information is available at the end of the article

\section{Background}

Members of the genus Sarcocystis are protozoan parasites characterized by an obligatory two-host prey-predator life-cycle. Asexual multiplication with sarcocyst formation occurs in the muscles and/or central nervous system (CNS) of the intermediate host (IH), whereas sexual original author(s) and the source, provide a link to the Creative Commons licence, and indicate if changes were made. The images or other third party material in this article are included in the article's Creative Commons licence, unless indicated otherwise in a credit line to the material. If material is not included in the article's Creative Commons licence and your intended use is not permitted by statutory regulation or exceeds the permitted use, you will need to obtain permission directly from the copyright holder. To view a copy of this licence, visit http://creativecommons.org/licenses/by/4.0/. The Creative Commons Public Domain Dedication waiver (http://creativeco mmons.org/publicdomain/zero/1.0/) applies to the data made available in this article, unless otherwise stated in a credit line to the data. 
multiplication stages, oocysts/sporocysts develop in the small intestine of the definitive host (DH) [1]. Currently, 27 valid Sarcocystis spp. using birds as IH are known [2].

Raptors are indicators of biodiversity and environmental health, and are are recognized in ecosystems as top predators and scavengers, and as flagship species [3]. Various birds of prey (eagles, hawks, falcons and owls) have been examined as possible DH [1]. A number of investigations have also looked at birds of prey as IH of Sarcocystis spp. [4-11]. The pathogenic species Sarcocystis falcatula may cause encephalitis in the free-ranging great horned owl (Bubo virginianus) [6], the golden eagle (Aquila chrysaetos) and the bald eagle (Haliaeetus leucocephalus) [7]. Likewise, an undescribed Sarcocystis sp. causing encephalitis has been detected in an immature northern goshawk (Accipiter gentilis atricapillus) from Minnesota [4]. Recently, Sarcocystis wobeseri was identified in the pectoral and cardiac muscles of the white-tailed sea eagle (Haliaeetus albicilla) [10]. Also, Sarcocystis halieti was detected in the brain and muscle tissue of a juvenile free-ranging little owl (Athene noctua) [11]. Thus, to date sarcocysts of three Sarcocystis spp., S. falcatula, S. halieti and S. wobeseri, have been recorded in the brains and tissues of birds of prey $[6,7,10,11]$. In another study, three morphological types of sarcocysts were detected in the Eurasian buzzard (Buteo buteo) and the long-eared owl (Asio otus), with one of the sarcocysts in the owl identified as S. otus [12]. However, this latter species is considered to be invalid [1].

In this article, we describe the molecular identification of $S$. haliet i in the muscles of birds of prey from Spain.

\section{Methods}

Between 2019 and 2020 tissue samples of the leg muscles of 59 birds of prey (Accipitriformes, Falconiformes and Strigiformes) were examined for Sarcocystis spp. (Table 1). The birds had been admitted to the Wildlife Recovery Centre in Ilundain (Navarra) (Spain). The samples were taken by the Center's veterinary staff while carrying out their routine diagnostic protocol for the cause of death of the birds, which were either brought to the Center as dead specimens or died there. This center is under the jurisdiction of the Government of Navarra and is managed by a public company, GAN-NIK. Muscle samples were kept frozen $\left(-20{ }^{\circ} \mathrm{C}\right)$ until studied for morphological detection of the sarcocysts. The prevalence of sarcocysts and infection intensity were evaluated in methylene blue-stained muscle samples, as previously described [13].

Muscle samples of infected birds were delivered to the Laboratory of Molecular Ecology, Nature Research Centre, Vilnius, Lithuania for detailed morphological and molecular analysis. The morphological characterization
Table 1 Birds of prey $(n=59)$ from Navarra (Spain) examined for Sarcocystis spp.

\begin{tabular}{lll}
\hline Order & Common name (species) & $\begin{array}{l}\text { Infected/ } \\
\text { examined }\end{array}$ \\
\hline Accipitriformes & Black kite (Milvus migrans) & $2 / 6$ \\
Accipitriformes & Western marsh harrier (Circus aeruginosus) & $1 / 1$ \\
Accipitriformes & Booted eagle (Hieraaetus pennatus) & $0 / 2$ \\
Accipitriformes & Common buzzard (Buteo buteo) & $0 / 4$ \\
Accipitriformes & Eurasian sparrowhawk (Accipiter nisus) & $0 / 1$ \\
Accipitriformes & Red kite (Milvus milvus) & $0 / 9$ \\
Accipitriformes & European honey buzzard (Pernis apivorus) & $0 / 1$ \\
Accipitriformes & Northern goshawk (Accipiter gentilis) & $0 / 3$ \\
Accipitriformes & Griffon vulture (Gyps fulvus) & $0 / 4$ \\
Falconiformes & Common kestrel (Falco tinnunculus) & $0 / 7$ \\
Strigiformes & Eurasian scops owl (Otus scops) & $0 / 13$ \\
Strigiformes & Long-eared owl (Asio otus) & $0 / 2$ \\
Strigiformes & Brown owl (Strix aluco) & $0 / 3$ \\
Strigiformes & Little owl (Athene noctua) & $0 / 3$ \\
\hline
\end{tabular}

of sarcocysts and bradyzoites was performed in freshsquashed samples. Sarcocysts with a small amount of host tissue were excised using two preparation needles, transferred to a drop of water on a microscope slide and measured under a light microscope (LM) at $\times 40-\times 1000$ magnification.

Genomic DNA was isolated from individual sarcocysts using the GeneJET Genomic DNA Purification Kit (Thermo Fisher Scientific Baltics, Vilnius, Lithuania). Partial 28S rDNA was amplified using the KL-P1F/KLP2R primer pair [14], and the complete internal transcribed spacer 1 (ITS1) region was amplified using the SU1F/5.8SR2 primer pair [15]. The thermocycling conditions of the PCRs were as described previously [13]. Visualization, purification, and sequencing of PCR products were carried out using a previously described protocol [16]. The sequences obtained in this study were compared with those of various Sarcocystis spp. using the nucleotide BLAST program (megablast option) [17]. The multiple alignment was conducted using the MUSCLE algorithm loaded in MEGA7 software [18]. Selection of a nucleotide substitution model and phylogenetic analysis under Bayesian inference were carried out using TOPALi v2.5 [19].

Sarcocysts were detected in methylene-blue stained muscle samples from the leg muscles of one of the black kites (Milvus migrans); however, they were not observed in the freshly squashed samples not stained with methylene blue. Therefore, the muscle sample of this bird was digested with pepsin according to the modified protocol of Dubey et al. [1]. Specifically, $5 \mathrm{~g}$ of leg muscle tissue was cut into small pieces and suspended in $15 \mathrm{ml}$ of saline 
solution (0.9\%). The suspension was then homogenized in a commercial blender at top speed for 2 min with breaks. The homogenate was transferred into a $150-\mathrm{ml}$ flask and $15 \mathrm{ml}$ of digestion solution was added (pepsin, $0.26 \mathrm{~g}$; $\mathrm{NaCl} 0.5$ g; water up to $15 \mathrm{ml}$; and $37 \% \mathrm{HCl}$ to $\mathrm{pH} \mathrm{1.1)}$. The entire contents of the flask were incubated at $37^{\circ} \mathrm{C}$ for $2 \mathrm{~h}$ and the suspension was used for DNA extraction. Genomic DNA was extracted as described above. External PCR primers were SU1F/5.8SR2 [15], and internal primers GsShalF1 (5'-GATAATTGACTTTACGCGCCA TTAC- $3^{\prime}$ ) and GsShalR1 (5'GTGCACATCCATATATGC TCATTCT- $3^{\prime}$ ) were designed specifically for this study. The first run of a nested PCR assay was conducted as described in [13]. The second run of a nested PCR assay was carried out in a final volume of $12.5 \mu \mathrm{l}$ consisting of $6.3 \mu \mathrm{l}$ of DreamTaq PCR Master Mix (Thermo Fisher Scientific Baltics), $0.5 \mu \mathrm{M}$ of each primer, $1 \mu \mathrm{l}$ from the first run of PCR and nuclease-free water. The thermocycling conditions were: 1 cycle at $95{ }^{\circ} \mathrm{C}, 5 \mathrm{~min}$; then $94{ }^{\circ} \mathrm{C} / 45 \mathrm{~s}$, $65^{\circ} \mathrm{C} / 45 \mathrm{~s}, 72{ }^{\circ} \mathrm{C} / 50 \mathrm{~s}$ for 35 cycles; with a final extension at $72{ }^{\circ} \mathrm{C}, 7 \mathrm{~min}$. Visualization, purification and sequencing of PCR products were performed as described above. Sequences generated in the present study were deposited in GenBank under accession numbers MW926916MW926917 and MW929599-MW929601.

\section{Results}

Sarcocysts were detected in tissue samples stained with methylene blue examined under the LM in three of the 59 (5.1\%) birds of prey: one western marsh harrier (Circus aeruginosus; isolate CaEs1) and two black kites (Milvus migrans; isolates MmEs1 and MmEs2). Two sarcocysts (isolates CaEs1 and MmEs1) were excised from fresh samples and subjected to amplification and sequencing of 28S rRNA and ITS1. Sarcocysts were not found in a fresh muscle sample from a single black kite (isolate MmEs2); therefore, this sample was digested and Sarcocystis DNA was amplified using a nested PCR targeting the ITS1 region.

From three to seven sarcocysts were observed in $1 \mathrm{~g}$ of methylene blue-stained muscle sample. Under the LM, one type of sarcocyst was observed. Sarcocysts seemed to be thread-like, $1560 \times 143 \mu \mathrm{m}$ (range: $1050-2160 \times$ $130-158 \mu \mathrm{m} ; n=6)$ in size, with a thin $(0.7-1.4 \mu \mathrm{m})$, apparently smooth cyst wall (Fig. 1a). The sarcocysts were clearly divided by septa into compartments filled with mature banana-shaped bradyzoites, $5.9 \times 1.7 \mu \mathrm{m}$ (range: $4.8-7.1 \times 1.3-2.1 \mu \mathrm{m} ; n=45$ ) in size (Fig. 1b).

The obtained 830-bp ITS1 sequence from the western marsh harrier (Circus aeruginosus) (isolate: CaEs1) was $100 \%$ identical with $S$. halieti from the great cormorant (Phalacrocorax carbo) (JQ733513, MH130209) and from the herring gull (Larus argentatus) (MN450340,

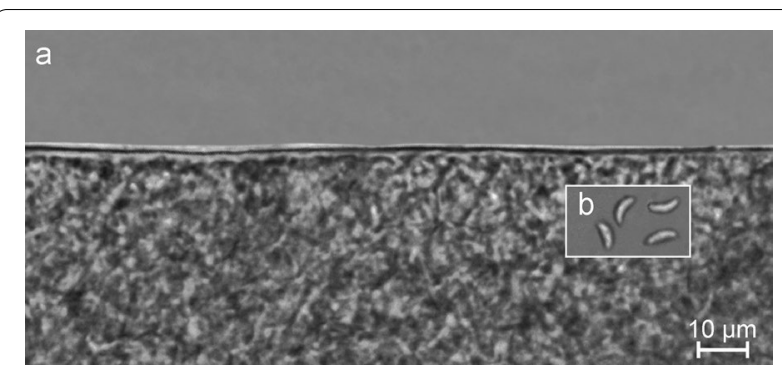

Fig. 1 Morphology of Sarcocystis halieti in tissue sample taken from the leg muscle of the black kite (Milvus migrans), fresh preparation. a Fragment of the smooth cyst wall, $\mathbf{b}$ banana-shaped bradyzoites

MN450341). The 569-bp ITS1 sequence generated from the digested muscle sample of the black kite (MmEs2) demonstrated $100 \%$ identity with $S$. halieti from the herring gull (MN450344-MN450356) and from the whitetailed eagle (MF946589, MF946590), whereas the 830-bp ITS1 sequences obtained for sarcocyst isolated from the black kite (MmEs1) showed $97.2-97.7 \%$ similarity to $S$. halieti from the herring gull (MN450340-MN450356), the white-tailed eagle (MF946589-MF946596) and the great cormorant (JQ733513, MH130209), had 96.0\% similarity to Sarcocystis sp. from the Chilean skua (Stercorarius chilensis) (MW160469), 93.2\% similarity to Sarcocystis sp. from the Cooper's hawk (Accipiter cooperii) (KY348755) and 92.3-92.5\% similarity to S. columbae from the herring gull (MN450338, MN450339) and from the woodpigeon (Columba palumbus) (GU253885, HM125052). The ITS1 sequences obtained from two black kites (MmEs1 and MmEs2) displayed 97.0\% similarity. In the ITS1 phylogenetic tree, the sequences from the black kites and the western marsh harrier were placed in one cluster together with those from S. halieti and Sarcocystis sp. from the Chilean skua (Fig. 2). It should be noted that the sequence from the black kite (MmEs1) formed a sister branch to the other $S$. halieti sequences. The 1488-bp 28S rRNA sequence from the black kite (MmEs1) differed by one to two single nucleotide polymorphisms (SNPs) from those of S. halieti (JQ733512, MF946610, MH130210) and by seven SNPs from those of S. columbae (HM125053), while the 1508-bp 28S rRNA sequence from the western marsh harrier (CaEs1) demonstrated $99.3-100 \%$ identity with that from S. halieti. Thus, on the basis of the molecular examination, S. halieti was identified in two black kites and a single western marsh harrier.

\section{Discussion}

The results of the present study reveal new IH for S. hali$e t i$, which we identified in the black kite and the western marsh harrier for the first time. A juvenile little owl was 


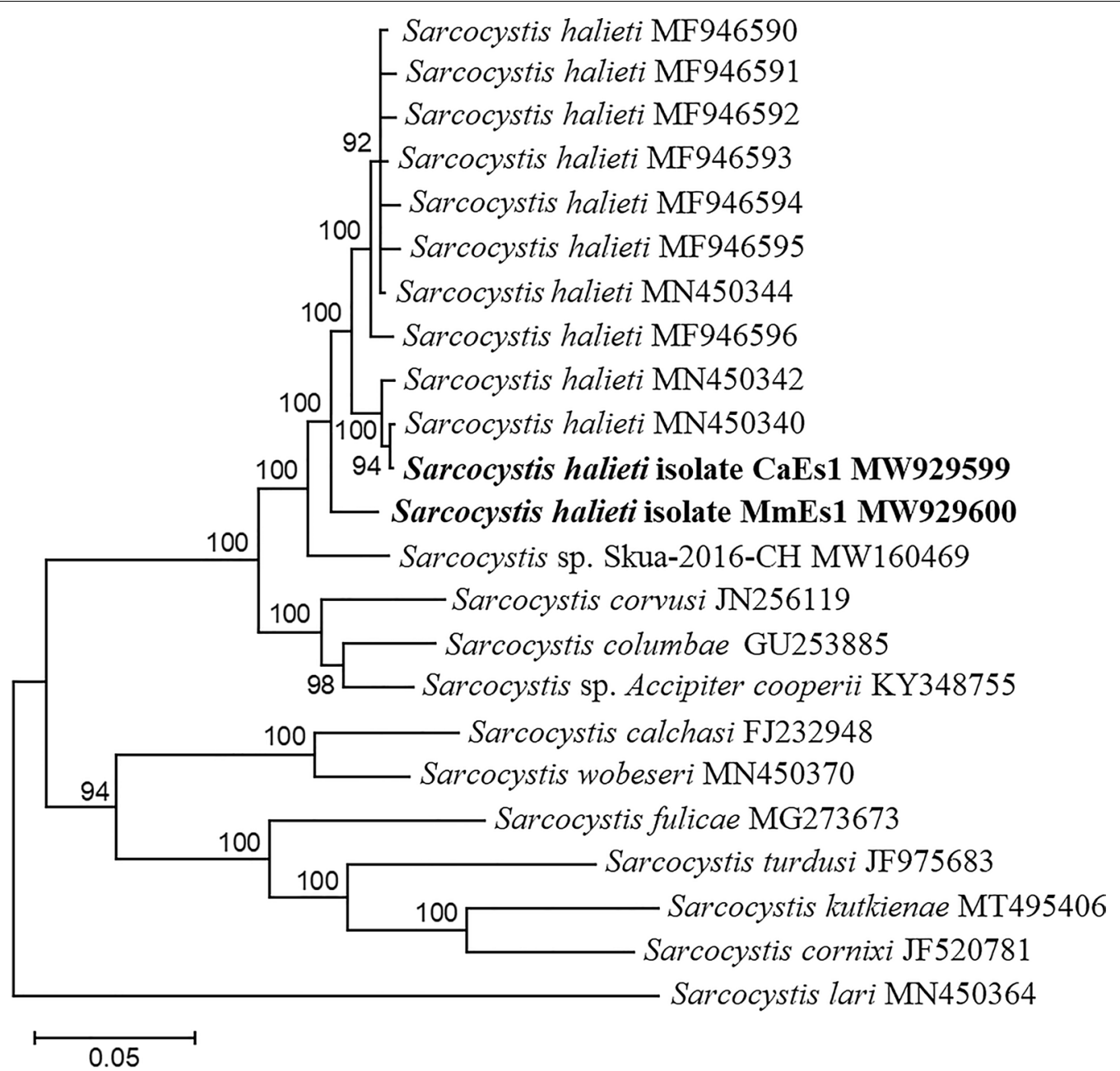

Fig. 2 Phylogenetic tree of selected Sarcocystis spp. based on internal transcribed spacer (ITS1) sequences. The tree was constructed using Bayesian methods, scaled according to the branch length and rooted on Sarcocystis lari. The final alignment of the ITS1 sequences contained 23 taxa and 982 aligned nucleotide positions. Numbers next to branches show the posterior probability support values. Sequences generated in the present study are indicated in boldface

recently diagnosed with granulomatous encephalitis and muscular sarcocysts caused by S. halieti [11]; earlier studies had detected S. halieti in the great cormorant [20] and the herring gull [21]. Our results extend the body of knowledge on S. halieti specificity for the IH and indicate that this species is able to form sarcocysts in birds belonging to at least four different orders: Accipitriformes (present study), Charadriiformes [21], Strigiformes [11] and Suliformes [20]. Other avian Sarcocystis spp. (i.e. S. calchasi, S. columbae, S. falcatula and S. wobeseri) can also form sarcocysts in $\mathrm{IH}$ belonging to different orders [1, $10,21,22]$. The development of molecular methods and expansion of the diversity of the host species examined had led to the detection of the known Sarcocystis spp. in different bird orders [22]. Such investigations are of particular importance in terms of pathogenic species. It should be noted that highly pathogenic Sarcocystis spp., such as S. neurona, S. canis, S. felis, S. calchasi and S. falcatula, are multi-host adapted [1], as exemplified by the recent detection of $S$. halieti-associated encephalitis in a little owl from Germany [11]. Therefore, further investigation of the pathogenesis of S. halieti in various birds is required and extensive histopathological studies of this pathogenic species are recommended.

Sarcocysts of $S$. halieti detected in the muscles of birds of prey seemingly differed morphologically from those previously described in other IH. For comparative purposes, sarcocysts of $S$. halieti isolated from the leg and neck muscles of the great cormorant were very long, up to $6.5 \times 0.1 \mathrm{~mm}$ [20], whereas sarcocysts excreted from 
the leg muscles of the herring gull were from $3960 \mu \mathrm{m}$ to $7930 \mu \mathrm{m}$ in length and from $43 \mu \mathrm{m}$ to $128 \mu \mathrm{m}$ in width [21]. Sarcocysts identified in the leg muscles of black kites and the western marsh harrier were, in comparison, shorter and wider $(1050-2160 \times 130-158 \mu \mathrm{m})$. Sarcocystis halieti sarcocysts of various shapes may be associated with diverse types of host anatomical structure. In terms of the distribution of muscle forces, accipitrids, falconids and strigiforms tend to possess greater proportions of distally inserted digital flexor musculature $(53-64 \%$, on average) [23]. On the other hand, the size of sarcocysts might depend on the contraction of the muscle fibers and the amount of pressure applied to the cover slip [1].

In the present study, sarcocysts were observed in three of the 59 (5.1\%) birds of prey from Spain that were studied, with the help of methylene blue staining. A similar low prevalence of infection was detected in raptorial birds from Germany (3/79, 3.8\%) [12] and Australia $(5 / 38,13.2 \%)$ [24] by histological examination. Based on pepsin digestion, significantly higher infection rates $(52 / 114,45.6 \%)$ were reported in birds of prey from the USA [5]. Whereas when examined by an immunofluorescence antibody test, eight of $72(11.1 \%)$ raptorial birds from Brazil were found to be positive for Sarcocystis spp. [25]. Altogether, previous studies suggest that the prevalence of Sarcocystis spp. infection in raptorial birds varies depending on the method used for examination of the tissue samples.

Due to a lack of published data from comprehensive microscopic examinations, it is difficult to compare the morphology of the sarcocysts of $S$. halieti identified in the present study with those observed in other birds of prey in previous studies. Based on LM examination, two types of sarcocysts were reported in bald eagles from the USA [26]. The first type of sarcocyst was microscopic, had a thin cyst wall with spines and contained bradyzoites $5 \times$ $1 \mu \mathrm{m}$ in size; the second type (type II) was immature and had a $2-\mu \mathrm{m}$-thick striated cyst wall [26]. These sarcocysts are not similar to those observed in our study. However, type II sarcocysts were detected in the Eurasian buzzard [12]; these measured 694-1850 × 42-235 $\mu \mathrm{m}$, had a seemingly smooth cyst wall and resembled those of $S$. halieti. A histological study detected thin-walled $(0.5 \mu \mathrm{m})$ sarcocysts with a smooth surface and no visible protrusions in the cardiac muscle of the white-tailed sea eagle from Norway [27]; the length of the sarcocysts was not determined, but the diameter of the largest cyst measured was $40 \mu \mathrm{m}$. Subsequently, S. wobeseri was identified in the muscles of the white-tailed sea eagle from the UK [10]. Based on current knowledge, the sarcocysts of $S$. halieti and $S$. wobeseri are morphologically indistinguishable [21]. Lastly, thin-walled $(\leq 1 \mu \mathrm{m})$ and thick-walled $(2-4 \mu \mathrm{m})$ sarcocysts were detected in the muscles of raptors from the south-eastern USA [8]; the thin-walled sarcocysts might represent those of $S$. halieti, S. wobeseri or of an otherwise not yet confirmed Sarcocystis spp.

The most detailed morphological examination of sarcocyst structure occurs using transmission electron microscopy (TEM) [1]. To date, only a few studies have used TEM to describe sarcocysts in raptorial birds [7, 12]. Based on TEM, the sarcocyst of Sarcocystis sp. found in the Eurasian buzzard and having a thin (up to $1.2 \mu \mathrm{m}$ ) and wavy cyst wall [12] is similar to that of S. halieti [20]. However, sarcocysts of $S$. halieti under the transmission electron microscope are very similar to those of $S$. calchasi, S. corvusi, S. fulicae, S. columbae, S. lari and $S$. wobeseri $[1,20,28]$. Also, four Sarcocystis species $(S$. columbae, S. halieti, S. lari and S. wobeseri) were identified in the herring gull [21]. Hence, molecular methods are needed for decisive discrimination of Sarcocystis spp. using birds as $\mathrm{IH}$.

The most recent studies on Sarcocystis spp. in birds of prey have focused on the diagnosis of this apicomplexan genus using muscle digestion and subsequent nested PCR [9] or an immunofluorescence antibody test [25]. These methods are relatively sensitive to the detection of Sarcocystis spp. However, even with these methods, morphological characteristics of sarcocysts, which are important to achieve phenotypic diagnosis of Sarcocystis spp., cannot be determined. In summary, studies on the role of birds of prey as IH of Sarcocystis spp. are fragmentary, and it is difficult to compare the results obtained by different morphological and molecular methods.

Eight Sarcocystis spp., namely S. accipitris, S. alectoributeonis, S. calchasi, S. columbae, S. cornixi, S. halieti, $S$. lari and $S$. turdusi, using birds as $\mathrm{IH}$ are transmissible by birds of prey $[1,27,29]$. The white-tailed sea eagle and the Eurasian sparrow hawk (Accipiter nisus) (family Accipitridae) have been confirmed to be DH of S. halieti $[27,29]$. In the present study, two bird species also belonging to family Accipitridae were shown to be $\mathrm{IH}$ of $S$. halieti. Hence, there is a possibility that accipitrids might be infected with $S$. halieti through cannibalism. Such diet behavior is common among raptorial birds, especially among members of the Accipitridae family (65.5\%) [30]. Future studies on the transmission of $S$. halieti are needed.

\section{Conclusions}

In the present study, S. halieti was identified in the black kite and the western marsh harrier from Navarra (Spain) by means of $28 \mathrm{~S}$ rDNA and ITS1 sequence analysis. This is the third Sarcocystis species to be detected in the muscles of birds of prey. Studies on Sarcocystis spp. from birds of prey are fragmentary. Therefore, further combined morphological, histopathological and molecular 
methods should be employed to provide a comprehensive description of Sarcocystis spp. found in birds of prey.

\author{
Abbreviations \\ CNS: Central nervous system; DH: Definitive host; IH: Intermediate host; \\ ITS1: Internal transcribed spacer 1; LM: Light microscope; rRNA: Ribosomal \\ RNA; SNP: Single nucleotide polymorphisms; TEM: Transmission electron \\ microscopy.
}

\section{Acknowledgements}

The research was supported by the Open Access research infrastructure of the Nature Research Centre under the Lithuanian open access network initiative.

\section{Authors' contributions}

Conceptualization: PP, AB, SŠ and DB; formal analysis: PP and Š̌; investigation: $E J N, A B, P P$ and $D B$; resources: $D V$ and $I O$; writing - original draft and prepara-

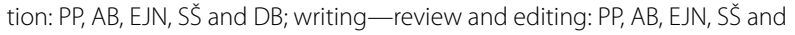
$D B$; visualization: $P P$ and $E J N$; supervision: $P P$ and $D B$; project administration: PP and SŠ; funding acquisition: AB, PP and SŠ. All authors read and approved the final manuscript.

\section{Funding}

Not applicable.

\section{Availability of data and materials}

Data supporting the conclusions of this article are included within the article The 28S rRNA and ITS1 sequences generated in the present study were submitted to the GenBank database under accession numbers MW926916MW926917 and MW929599-MW929601, respectively.

\section{Declarations}

\section{Ethics approval and consent to participate}

The dead birds were collected with the permission of the Government of Navarra (RESOLUTION 249/2019, 23/12/2019).

\section{Consent for publication}

Not applicable.

\section{Competing interests}

The authors declare that they have no competing interests.

\section{Author details}

${ }^{1}$ Nature Research Centre, Akademijos 2, 08412 Vilnius, Lithuania. ${ }^{2}$ Ekos Estudios Ambientales S.L.U., Donostia Etorbidea 2, Bajo 2, 20160 Lasarte, Spain. ${ }^{3}$ Navarra Environmental Management GAN-NIK, Calle Padre Adoain 219, 31015 Pamplona, Spain.

Received: 3 May 2021 Accepted: 3 August 2021

Published online: 18 August 2021

\section{References}

1. Dubey JP, Calero-Bernal R, Rosenthal BM, Speer CA, Fayer R. Sarcocystosis of animals and humans. 2nd ed. Boca Raton: CRC Press; 2016.

2. Máca O, González-Solís D. Sarcocystis cristata sp. nov. (Apicomplexa, Sarcocystidae) in the imported great blue turaco Corythaeola cristata (Aves, Musophagidae). Parasit Vectors. 2021;14:56.

3. Donázar JA, Cortés-Avizanda A, Fargallo JA, Margalida A, Moleón M, Morales-Reyes $Z$, et al. Roles of raptors in a changing world: from flagships to providers of key ecosystem services. Ardeola. 2016;63:181-234.

4. Aguilar RF, Shaw DP, Dubey JP, Redig P. Sarcocystis associated encephalitis in an immature Northern goshawk (Accipiter gentiles atricapillus). J Zoo Wildl Med. 1991:22:466-9.

5. Lindsay DS, Blagburn BL. Prevalence of encysted apicomplexans in muscles of raptors. Vet Parasitol. 1999;80:341-4.
6. Wünschmann A, Rejmanek D, Cruz-Martínez L, Barr BC. Sarcocystis falcatula-associated encephalitis in a free-ranging great horned owl (Bubo virginianus). J Vet Diagn Invest. 2009;21:283-7.

7. Wünschmann A, Rejmanek D, Conrad PA, Hall N, Cruz-Martinez L, Vaughn SB, Barr BC. Natural fatal Sarcocystis falcatula infections in free-ranging eagles in North America. J Vet Diagn Invest. 2010;22:282-9.

8. Von Dohlen AR, Scott D, Dubey JP, Lindsay DS. Prevalence of Sarcocysts in the muscles of raptors from rehabilitation center in North Carolina. J Parasitol. 2019:105:11-6.

9. Rêgo WMF, Costa JGL, Baraviera RCA, Pinto LV, Bessa GL, Lopes REN, et al. Sarcocystidae in wild birds of southeastern Brazil. Braz J Vet Parasitol. 2021;30:e028520

10. Shadbolt T, Pocknell A, Sainsbury AW, Egerton-Read S, Blake DP. Molecular identification of Sarcocystis wobeseri-like parasites in a new intermediate host species, the white-tailed sea eagle (Haliaeetus albicilla). Parasitol Res. 2021;120:1845-50.

11. Maier-Sam K, Kaiponen T, Schmitz A, Schulze C, Bock S, Hlinak A, Olias P. Encephalitis associated with Sarcocystis halieti infection in a free-ranging little owl (Athene noctua). J Wildl Dis. 2021;57:712-4.

12. Krone $\mathrm{O}$, Rudolph $\mathrm{M}$, Jakob W. Protozoa in the breast muscle of raptors in Germany. Acta Protozool. 2000;39:35-42.

13. Prakas P, Butkauskas D, Juozaitytè-Ngugu E. Molecular and morphological description of Sarcocystis kutkienae sp. nov. from the common raven (Corvus corax). Parasitol Res. 2020;119:4205-10.

14. Kutkienè L, Prakas P, Sruoga A, Butkauskas D. The mallard duck (Anas platyrhynchos) as intermediate host for Sarcocystis wobeseri sp. nov. from the barnacle goose (Branta leucopsis). Parasitol Res. 2010;107:879-88.

15. Gjerde B. Molecular characterisation of Sarcocystis rileyi from a common eider (Somateria mollissima) in Norway. Parasitol Res. 2014;113:3501-9.

16. Prakas P, Butkauskas D, Rudaitytè E, Kutkienè L, Sruoga A, Püraitè I. Morphological and molecular characterization of Sarcocystis taeniata and Sarcocystis pilosa n. sp. from the sika deer (Cervus nippon) in Lithuania. Parasitol Res. 2016;115:3021-32.

17. Altschul SF, Gish W, Miller W, Myers EW, Lipman DJ. Basic local alignment search tool. J Mol Biol. 1990;215:403-10.

18. Kumar S, Stecher G, Tamura K. MEGA7: molecular evolutionary genetics analysis version 7.0 for bigger datasets. Mol Biol Evol. 2016;33:1870-4.

19. Milne I, Wright F, Rowe G, Marshall D, Husmeier D, McGuire G. TOPALi: software for automatic identification of recombinant sequences within DNA multiple alignments. Bioinformatics. 2004:20:1806-7.

20. Prakas P, Butkauskas D, Švažas S, Stanevičius V. Morphological and genetic characterisation of Sarcocystis halieti from the great cormorant (Phalacrocorax carbo). Parasitol Res. 2018;117:3663-7.

21. Prakas P, Butkauskas $D$, Juozaitytè-Ngugu E. Molecular identification of four Sarcocystis species in the herring gull, Larus argentatus, from Lithuania. Parasit Vectors. 2020;13:2

22. Bamac O, Rogers K, Arranz-Solís D, Saeij J, Lewis S, Duerr R, et al. Protozoal encephalitis associated with Sarcocystis calchasi and S. falcatula during an epizootic involving Brandt's cormorants (Phalacrocorax penicillatus) in coastal Southern California, USA. Int J Parasitol Parasites WildI. 2020;12:185-91.

23. Spencer BB, Diego S, Lael UO, Aaron MD. Mechanical analysis of avian feet: multiarticular muscles in grasping and perching. R Soc Open Sci. 2015;2:140350.

24. Munday BL, Hartley WJ, Harrigan KE, Presidente PJA, Obendorf DL. Sarcocystis and related organisms in Australian wildlife: II. Survey findings in birds, reptiles, amphibians and fish. J Wildl Dis. 1979;15:57-73.

25. Sato AP, Goulart MA, Konell AL, de Oliveira Koch M, da Fonseca FM, Morel AP, et al. Serosurvey of Toxoplasma gondii, Neospora caninum and Sarcocystis neurona in raptors and risk factor analysis. Parasitol Int. 2021;82:102312.

26. Crawley RR, Ernst JV, Milton JL. Sarcocystis in a bald eagle (Haliaeetus leucocephalus). J Wildl Dis. 1982;18:253-5.

27. Gjerde B, Vikøren T, Hamnes IS. Molecular identification of Sarcocystis halieti n. sp., Sarcocystis lari and Sarcocystis truncata in the intestine of a white-tailed sea eagle (Haliaeetus albicilla) in Norway. Int J Parasitol Parasites Wildl. 2018;7:1-11.

28. Prakas P, Butkauskas D, Švažas S, Juozaitytè-Ngugu E, Stanevičius V. Morphologic and genetic identification of Sarcocystis fulicae n. sp. (Apicomplexa: Sarcocystidae) from the Eurasian coot (Fulica atra). J Wildl Dis. 2018:54:765-71. 
29. Mayr SL, Maier K, Müller J, Enderlein D, Gruber AD, Lierz M. Accipiter hawks (Accipitridae) confirmed as definitive hosts of Sarcocystis turdusi, Sarcocystis cornixi and Sarcocystis sp. ex Phalacrocorax carbo. Parasitol Res. 2016;115:3041-7.

30. Allen M, Inagaki A, Ward MP. Cannibalism in raptors: a review. J Raptor Res. 2020;54:424-30.

\section{Publisher's Note}

Springer Nature remains neutral with regard to jurisdictional claims in published maps and institutional affiliations.
Ready to submit your research? Choose BMC and benefit from:

- fast, convenient online submission

- thorough peer review by experienced researchers in your field

- rapid publication on acceptance

- support for research data, including large and complex data types

- gold Open Access which fosters wider collaboration and increased citations

- maximum visibility for your research: over 100M website views per year

At BMC, research is always in progress.

Learn more biomedcentral.com/submissions 